\author{
Анатолій Загнітко \\ Донецький національний університет імені Василя Стуса \\ Український мовно-інформаційний фонд \\ Національної академії наук України \\ a.zagnitko@donnu.edu.ua
}

Anatoly Zagnitko

Vasyl' Stus Donetsk National University

Ukrainian Lingua-Information Fund

of NAS of Ukraine

a.zagnitko@donnu.edu.ua

\title{
ПРИЙМЕННИКОВО-ПРОСТОРОВА СЕМАНТИКА В СУЧАСНИХ ІНТЕРПРЕТАЦІЯХ: ГРАМАТИЧНИЙ I ЛЕКСИКОГРАФІЧНИЙ ВИМІРИ
}

\author{
PREPOSITIONAL AND SPATIAL SEMANTICS \\ IN MODERN INTERPRETATIONS: GRAMMATICAL \\ AND LEXICOGRAPHIC DIMENSIONS
}

У статті систематизовано еволюцію поглядів на прийменник та їх кваліфікацію у формальному (формально-граматичному), семантичному, функційно-комунікативному, функційно-когнітивному вимірах із зосередженнях уваги на прийменниково-просторовій семантиці, яку визначено як первинну та ієрархічно вершинну у функційно-когнітивному та функційно-комунікативному вимірах. Просторова семантика формує ядро прийменникової системи, її поступова редукція (↔ втрата) зумовлює витворення функційно цілісних сполук слів, у яких приприйменниковий компонент граматизується та постає актуалізатором просторового параметру — глибини, довжини, ширини, висоти, а первинна предметна семантика нейтралізується, залишається лише формально-граматичний зміст. Запропоновано лексикографічний профіль прийменника просторової семантики.

Ключові слова: прийменник, прийменникова одиниця, прийменниково-просторова семантика, реченнєвий специфікатор, приприйменниковий компонент, придієслівна позиція, прийменниковий профіль.

The article systematizes the evolution of views on prepositions and their qualifications in formal (formal-grammatical), semantic, functional-communicative, functionalcognitive dimensions with a focus on prepositional-spatial semantics, which is defined as a primary and hierarchically apical in functional-cognitive and functional-communicative dimensions. Spatial semantics forms the core of the prepositional system, its gradual reduction ( $\leftrightarrow$ loss) determines the creation of functionally integral junctions of words, in which 
the prepositional component is grammatized and appears as an actualizer of the spatial parameter - depth, length, width, height, and the primary subject semantics is neutralized, only the formal grammatical content remains. A lexicographic profile of the preposition of spatial semantics is proposed.

Key words: preposition, prepositional unit, prepositional-spatial semantics, speech specifier, prepositional component, preverb position, prepositional profile.

0. Прийменник у його класичному та сучасному розуміннях зберігає основну тяглість у кваліфікації: 1) частиномовного статусу (службового, неповнозначного, несамостійного і т. ін.); 2) функційного навантаження в синтаксичних одиницях - від елементарної (синтаксичне слово, синтаксема) до словосполучення, речення, тексту, дискурсивних практик; 3) актуалізаційних вимірів різних відношень - об'єктних, атрибутивних, суб'єктних та ін. Не менш проблемним залишається й визначення граматичності й семантичності прийменникових одиниць, встановлення шляхів поповнення прийменникової системи та простеження регулярності i/ чи обов'язковості сполучуваності з дієслівними (у постпозиції) та іменниковими (у препозиції i/ чи постпозиції) елементами. Зміна лінгвонаукових парадигм (елементно-таксонімічної (дососсюрівської), системно-структурної (соссюрівської), когнітивно-функційної (постсоссюрівської)) щоразу активізує спроби переосмислення статусу прийменника, розглянути його не лише в суто формально-граматичному вимірі, а й скваліфікувати стилістичне закріплення й навантаження в дискурсивних практиках (функційно-комунікативний підхід), виявити синтаксемнотвірний потенціал (семантикосинтаксичний аналіз), визначити можливості структурування й концептуалізації довкілля (функційно-когнітивний погляд), розкрити текстотвірний статус (лінгвотекстовий аналіз) і под. Сучасне розуміння прийменника загалом та одиниць прийменниково-просторової семантики зокрема вимагає осмислення загальних підходів до його кваліфікації та відносної систематизації поглядів.

1. Еволюція пілходів до розгляду прийменника в її системному узагальненні передбачає виокремлення декількох етапів 1 , 3-поміж яких значущими постають: 1) кваліфікація прийменника як «частини слова людського» (Аристотель); 2) віднесення прийменників до несамостійних частин мови (у М. В. Ломоносова (1952) самостійними, чи повнозначними, були лише іменник і дієслово, а прийменник у його інтерпретації охоплює й сучасні власне прийменники (непохідні — ix 19 (за Конюшкевич 2007: 14-19), і префікси (подібно і в Востокова 1980: 115); 3) розуміння прийменника як формального слова без власного значення, що реалізує функцію «зв’язки об’єкта» (Потебня 1985: 36) чи суто формального класу слів (Шахматов 1941: 504), які не мають фразового наголосу, а лише поєднують два слова чи дві

1 У статті не робиться спроба виділення історично змінюваних підходів до тлумачення прийменника, оскільки подібне завдання вимагає окремого розгляду. 
групи слів «у синтагму (найпростіше синтаксичне ціле)» та виражають відношення означуваного до означувального (Щерба 1974: 77-100); 4) диференціювання у прийменників прямого й переносного значень (Востоков 1980: 115); 5) встановлення спроможності прийменника додавати певний відтінок у значення слів і словосполучень (Пєшковський 2001: 66). Водночас О. М. Пєшковський наголошує, що в складі прийменниково-відмінкової форми (ключ от замка) прийменник постає як «один складний звуковий показник граматичного значення, який частиною увійшов до складу одного із поєднуваних слів (замк-a), а частиною припав до нього як службовий (от замка)» (2001: 59); 6) розгляд синтаксичного статусу прийменників, за яким вони $€$ «частками речення» 3 основним призначенням бути «зв'язкою додатків та обставин з іншими частинами речення. Керувати відмінками - це прямий обов'язок прийменників, у цьому їхнє покликання. До цієї ролі також підлаштовується їхнє лексичне значення, постаючи лише способом вираження відомих відношень» (Овсянико-Куликовський 1902: 218); 7) характеристика прийменників як слів із власним лексичним значенням (Кучеренко 2003: 202-204); 8) кваліфікація прийменника як відмінкового форманта (Мєщанінов 1978: 357) з наголошенням, що «синтаксично ні сполучники, ні тим паче прийменники ніколи не займають самостійної позиції й ніколи не можуть бути самостійним членом речення чи його складником із власним цілісним лексико-синтаксичним змістом» (Там само: 357), тому вони «ніколи не були й не могли бути частинами мови» (Там само: 357$)$; 9) розуміння прийменника як особливої морфеми (автор концепції $Є$. Курилович 2000: 187) з розглядом у морфологічному, синтаксичному та словотвірному статусі. У межах цього підходу вагомими $€$ напрацювання І. Р. Вихованця (1984), В. М. Русанівського (1981: 9-20) та ін. Для Д. М. Шмельова прийменник у структурі прийменниково-відмінкових сполук «€ чинником граматичного оформлення іншого слова, поряд з афіксами» (1973: 60), а Ю. С. Степанов уважає прийменник «довгою перервною морфемою», що дає змогу аналізувати його спільно із закінченням як функційно цілісну, аналітичну відмінкову форму і в цьому разі роль прийменника тотожна закінченню (1968: 39). Посилювальним чинником аналізованого підходу є те, що прийменник набуває власного значення лише в структурі синтагм, тобто в поєднанні з повнозначним словом, що свідчить про його а) аналітичність; б) семантичну похідність (значення $\epsilon$ синтагмально похідним); в) конструктивне підпорядкування (пор.: Садирова 2014: 16)). Функційно-синтаксичний підхід покликав до життя поняття граматичної лексеми, яку потрібно витлумачувати як парадигмальну видозміну іменника з її відповідним використанням у тій чи тій синтагмі, конструкції, де прийменник позначає певні відношення; 10) кваліфікація прийменника з опертям на мовносоцімну об'єктивну й суб'єктивну стихію, що дає змогу розкрити мережу парадигмальних відносин у межах прийменникового функційно-граматичного поля, сформувалася на межі XX і XXI століть. «Системні зв'язки між прийменниками формують граматику прийменника 
як частини мови, яка, поряд із парадигматикою, охоплює й різноманітні аспекти функціювання прийменників у дискурсі» (Виноградова 2018: 230). Усталення концептуальних засад функційно-граматичного та функційнокомунікативного підходів до аналізу прийменникових одиниць відбулося в рамках міжнародного наукового проєкту «Слов'янські прийменники в синхронії та діахронії: морфологія і синтаксис» (автор ідеї М. В. Всеволодова), що стало підгрунтям для створення низки новітніх словників прийменників та їхніх аналогів (еквіприйменників) окремих слов'янських мов (білоруської - М. І. Конюшкевич (2008-2010); української - А. П. Загнітко (2007), російської - М. В. Всеволодова, К. М. Виноградова, Т. Є. Чаплигіна (2018), польської — Ч. Ляхур (Lachur 2019) та ін.).

У межах окреслених підходів розглядали прийменник більшість лінгвістів. Так, наприклад, В. В. Виноградов вважав прийменники частками мовлення, основною функцією яких є вираження просторових, часових, причинових, цільових, присвійних, обмежувальних та інших відношень між об'єктами, а також відношень об'єктів до дії, станів і якостей (1947: 677; 2001: 555-576). Такий погляд, очевидно, мав опертям підхід О. Ссперсена (його праця «The Philosophy of Grammar» побачила світ у 1924 році), для якого прислівники, прийменники, сполучники й вигуки є частками (1958: 76) з наголошенням, що граматика розглядає питання про вираження прийменниками перебування у певному місці або ж рух (віддалення чи наближення), питання про взаємовідносини між локальними й часовими значеннями того самого прийменника (Есперсен 1958: 25). Лінгвіст покликається на твердження Г. Шухардта, піддаючи його певним сумнівам: «Існує лише одна граматика, яка називається наукою про значення, або, правильніше, наукою про позначення... і словник не містить нічого, чого б не було в граматиці; словник подає алфавітний покажчик до неї» (Hugo SchuchardtBrevier, 127) цит. за (Есперсен 1958: 25)). Не менш показовим є визнання за прийменниками особливого семантичного характеру, який у більшості замкнутий на синтаксис (Fonstreuter — Egerer-Moslein 1978), що ускладнює цілісний опис прийменника. Останній завжди виявлюваний в оточенні щонайменше двох функційно навантажених повнозначних елементів. Тому можна говорити про право- та лівобічний контексти прийменника, пор., наприклад: (1) Грек дав мені шматок крейди і я написав на камені Приховане Ім'я (В. Сшкілєв, О. Гуцуляк) і (2) Після артистів лишилися порожні корчаги од вина і напис на камені «Смерть фашистам!» (М. Дочинець), де написав ( $\rightarrow$ на чому? + де?) на камені - об'єктні + локативні, напис $(\rightarrow$ на чому? + де? + який?) на камені - об'єктні + локативні + атрибутивні. У (1) правобічний контекст виражений дієсловом активної валентності (наnuсав), а лівобічний - іменником статичного простору (камені), що й відповідно зумовлює синкретизм відношень, наявність у (2) правобічного елемента (наnис), що зберігає лексико-семантичну дієслівність твірного, й водночас формально-граматична предметність проєктує залежну атрибутивність. 
2. Істотним є те, що в сучасній лінгвістиці простежується переосмислення різних поглядів на прийменник, що й дає змогу диференціювати: a) утрадиційнений формально-граматичний підхід з опертям на службовий статус прийменникових слів («розряд службових, морфологічно незмінюваних слів», «службова частина мови» (Всеволодова 2002: 14-25, Конюшкевич 2008: 60-66), «синсемантичне слово» (Ляхур 2008: 76-79), частка мови (Виноградов 1947: 677; 2001: 555-576), «слівний знак» (Уфимцева 2020: 128-132), «зв’язкове слово» (Згулкова (Zgółkowa 1980); б) новий лексично орієнтований, за яким прийменник $\epsilon$ лексично повнозначним (Кучеренко 2003). Наголошуючи на лексичному значенні прийменника, розмежовують загальне й часткове значення, де перше корелює з кваліфікацією прийменника як просторового, темпорального та ін., а останнє - 3 тими елементами, що відмежовують один прийменник від іншого: $н a-y(\varepsilon)-n i d$, пор: (3) Я згорнув аркуш удвоє і поклав на стіл (Р. Андріяшик); (4) Я поклав y траву цигарку і подивився на руки (Р. Андріяшик); (5) Горобенко повернувся горілиць і поклав під потилицю руки (Б. Антоненко-Давидович), де в (3) - окреслення поверхні, у (4) - позначення внутрішнього простору, а в (5) - нижня межа простору; в) новітній аналітично синтаксичний, у якому підгрунтям $\epsilon$ визначення прийменника як «аналітичної синтаксичної морфеми» (Вихованець 1984: 132), «класу службових морфологічно незмінюваних слів і класу фразеологізмів з релятивним (відносним) значенням» (Суровцева 2011: 120-126), «синтаксичної одиницї» (Урисон 2017 : 36-55), «граматичного засобу» (Нагайцева 2015: 5-7); г) синергійний функційно-комунікативний та функційно-когнітивний зі встановленням функційного поля прийменника та ін.

Семантико-синтаксичний аналіз прийменника грунтований на розкритті його регулярності у валентнозумовлених і вільних позиціях та встановленні співвідносності з функційно-комунікативним навантаженням. Семантико-синтаксичний статус прийменника здебільшого пов'язаний через підпорядкування з вираженням тих чи тих відношень: (6) В неділю він вичісувався, одягав нову чумарку, несміливо пробирався на крилас і співав з насолодою, закриваючи очі й викидаючи якісь свої заплутані коліния (М. Івченко) - в неділю (фоновий темпоральний детермінант або специфікатор обов'язковий (за Мустайоки 2006: 356), на крилас (обов'язковий валентнозумовлений фінальний локатив), з насолодою (характеризувальний детермінант), Прийменник реалізує спільно з іменниково-відмінковим закінченням підпорядкування в синтаксичних формах мотивованого i/чи немотивованого керування, прилягання як виявах підрядного прислівного синтаксичного зв'язку: (7) В неділю вичісувався, співав з насолодою, пробирався на крилас - синтаксична форма прилягання. Прийменник семантично обтяжений у межах словосполучення й речення, виражаючи підпорядкування одного повнозначного слова іншому, пор.: (8) Я сонно глипнув на замуровану інеєм шибку, на язики снігу, надутого за ніч на підвіконня поміжс трухляві рами (Р. Андріяшик) (глянув на (опосередкованість сло- 
восполученням $\operatorname{PartN}_{4} \rightarrow$ замуровану інесм) шибку; глипнув на язики; надутого на підвіконня; надутого за ніч; надутого поміж рами), де в конструкціях на $+\mathbf{N}_{4}$ локативне відношення $(\rightarrow$ куди?) нашаровується на первинне об'єктне (на що?). Обидва значення є субстанційними, з-поміж яких перше охоплює поверхню певного предмета, а друге - актуалізований предмет. У словосполученні ж надутого поміж рами (поміж $+\mathbf{N}_{4}$ ) адлативне значення репрезентує простір всередині предмета, об'єктне ж- постає розмитим, імпліцитним, функційно (функційно-комунікативно) домислюваним. Значення прийменників у конструкціях $\mathbf{V}_{\mathbf{f}} \mathbf{P r e p}$ на/поміж $\mathbf{N}_{\mathbf{4}}$ постає складником семантичної структури пропозиційного відмінка (Cook 1989: 182-191), що є обов'язковим валентнозумовленим компонентом і належить до глибинної реченнєвої структури. Такі конструкції репрезентують один із виявів позиційного силового поля прийменника. А в конструкції на + $\mathbf{L o c}_{\mathbf{6}}$, заповнюючи валентнозумовлену синтаксичну позицію суб'єкта, прийменник почасти реалізує локативну квазіфункцію з діатетичним зсувом: (9) А далі й забули про нього на селі (Б. Антоненко-Давидович). Діатетичний зсув зумовлений комунікативним рангом суб’єкта (↔ суб’єктний локатив) та особливостями ситуативно-прагматичної мотивації: прагненням учасника i/чи спостерігача називати або імплікувати суб’єкт, переміщуючи фокус уваги на його місцезнаходження (пор.: (Падучева 1997: 18-30). Подібні вияви прийменника мають опертям його функційно-комунікативний статус.

3. Просторово-прийменникову семантику потрібно розглядати в граматичному й лексикографічному вимірах. Здебільшого в різних дослідженнях (Вихованець 1984: 19-199) та граматиках (Вихованець - Городенська 2004: 330-331, 333-342), словниках (СУМ 11; СУМ 20) кількість просторових прийменників з урахуванням фонетичних та інших варіантів, а також одиниць, які виявляють прийменникову семантику лише в одному зі значень, варіюється від 40 до 150 й більше: біля, близько, близько від, близько до, близько з, в/у, вглиб, вглибині (у знач.), вздовж/уздовж, від/од, відносно, впоперек/упоперек, впродовж/упродовж, вслід/услід (у знач.), вслід/услід за, до, довкола/довкіл, довкруг/довкруги, за, збоку (у знач.), збоку від, з боку, зверх, зверху, з-за, з-меж/з-між/з-межи, з-над, з-перед, з-під/із-під, 3-поза, з-поміж, з-понад, з-попід, з-посеред, із ↔з зі, із-за, з-поміж/ізпоміж, з-проміж, зовні, зовні від, зсередини, к (рідко), кле (заст.), крізь, між, на, навздогін/наздогін, навколо (у знач.)/навкіл, навкруги/навкруг, навперейми, навпроти, навпроти від, над/наді/надо, навпроти/напроти (у знач.), назад, назад до, назустріч (у знач.)/навстріч, наперед, напереріз, напроти, нарівні, нарівні з, насеред, насупроти, на чолі, недалеко, недалеко від, неподалік, неподалік від, нижче, обабіч, обік, обіруч, обіруч від, обіч, обіч від, оддалік (віддалік), оддалік (віддалік) від, округ/округи, осторонь, осторонь від, паралельно, перед/переді/передо, перпендикулярно з, по, побіч, побіч з, поблизу/поблиз, поверх, повздовж/подовж, повище, поза, позад/позаду, 
поздовж, поміж/помежи, понад/понадо/понаді, понижче, поодаль, попереду, поперек, попід, попри, поруч, поруч з, посередині (третє значення), посеред, починаючи від, праворуч, праворуч від, при, проз, проміж, просто, проти, серед, слідом за, спереду, спереду від, супроти, убік, убік від, убік до, у напрямі, у напрямі до, у напрямку, у напрямку до, упоперек від, через та ін. Уже побіжний погляд на перелік просторових прийменників свідчить про наявність 3-поміж них первинних із широким семантико-синтаксичним і функційно-комунікативним діапазонами (в/y, до, за, над, nid, no, $n p u$ і под.) та вторинних, що внутрішньо диференційовані на інформативно недостатні й інформативно достатні. Перші охоплюють прийменники: а) неспіввідносні ні семантично, ні формально з будь-якою частиною мови, але $з$ відчутним значеннєвим залишком мотивата (крізь); б) нерозкладні прийменниково-похідні одиниці, що постали внаслідок об'єднання двох і більше первинних (3-за, з-меж/3-між, з-над/із-над, з-під/із-під, з-понад/ із-понад, з-попід/із-попід, заради, поза/з-поза/із-поза, попід/nопіді/nопідо).

Інформативно достатні просторові прийменники в загальному обширі містять: 1) кореляти з морфологізованими прислівниками (близько, вгорі угорі, вглиб/углиб, вздовж/уздовж, вище, вподовж/уподовж, віддалік/оддалік/оддалеки, впоперек/упоперек, всередині/усередині, всупереч/усупереч, довкола/довкіл, напередодні, наприкіниі, напроти/навпроти, недалеко, неподалік, нижче, обабіч, поблизу, поверх, позаду, попереду, спереду, супроти та ін.); 2) іменниково-відмінкові адвербіати (кінеиь, коло, край, круг, кругом і под.); 3) прийменниково-іменникові адвербіати (з $\rightarrow$ із боку, в/y $\rightarrow$ в/y глибині, в/у напрямі, в/у напрямку, в/у просторі і т. ін.); 4) граматизовані прислівники з первинними прийменниками (близько від, близько до, далеко від, в/у напрямі, в/у напрямку, збоку від, ліворуч від, побіч з/із/зі/зо, праворуч з, праворуч до та ін.). Лексикографічне тлумачення детермінує рівень усталення прийменника з диференціюванням $у$ знач., у функиії та ін.

4. Аналізуючи увесь загал прийменників, І. Р. Вихованець вирізнив 3-поміж них 137 просторових (1984: 218), а Г. С. Балабан доповнила склад директивних (адитивних) прийменників: в/у напрямі від, в/у напрямку від, на шляху від, в/у дорозі з/із, на шляху до, прямуючи до, в/у дорозі до, водночас склад локативних прийменників розширено за рахунок таких одиниць: на теренах, в/у зоні (зонах), в/у районі (районах), в/укордонах, в/у стінах, поза стінами, в/у сусідстві (2007: 5-6). Л. А. Тарасевич, з опертям на фундаментальні граматики, нараховує в російській мові лише 44 просторові прийменники, а в німецькій — 39 (Тарасевич 2014: 41), що можна пояснити обмеженою фактологічною базою (пор., наприклад, спостереження М. В. Всеволодової (2012a; 2012b) та ін.). Цілком очевидно, що констатовані одиниці $є$ нерівнорядними у функційно-когнітивному вияві. Якщо множина традиційно кваліфікованих прийменників (в/y, вглиб/углиб, вище, за, на, нижче, по та ін.) не викликає сумнівів у їх статусі засобів зв'язку (формально-граматичний рівень) та окресленні семантики в межах реалізова- 
них відношень (семантико-синтаксичний рівень), то в іншій множині просторових прийменників потрібно диференціювати чотири основні групи: 1) слова, вжиті у значенні прийменників (в/y напрямі від, в/у напрямку до, поодаль від, оподаль від та ін.); 2) слова, що реалізують функцію прийменників (поза межами, за межами і под.); 3) аналоги прийменників (з/із глибини від ... до, з/із висоти від ... до, з відстані від ... до, у/в межах проєкту, y/в рамках/рамах дослідження і т. ін.); 4) слова з оказіональним прийменниковживанням (на горизонті науки, на відстані сльози і под.) (Загнітко 2007: 9-14). Прийменники просторової семантики постають досить активно поповнюваними за рахунок другого - третього різновидів, що у своїй сукупності становлять строкату множину. Для її цілісного розгляду загалом та кожної одиниці зокрема доцільно використати обгрунтоване поняття функційно-семантичного поля прийменника (Всеволодова 2012a; 2012b; Виноградова 2018), що охоплює первинні прийменники 3 похідними, які виконують функцію прийменника — від оприйменникованих до тих, що перебувають на певному етапі граматизації з чітко окресленою внутрішньою формою, пор.: з/iз/зi/зо $\rightarrow$ iз /зі сфери чого, з/iз/зi/зо $\rightarrow$ 3/iз межс чого, з/із/зі/зо $\rightarrow$ з/із рамок чого, за сферу чого, за межі чого, за рамки чого та ін. Привертає увагу аналітизм таких утворень - наявність двох і більше лексем. Інтенсивний процес розширення прийменникового корпусу найбільш спостережуваний у мовносоціумній об'єктивній і суб'єктивній граматиці, шо охоплює незліченну кількість дискурсивних практик: (9) $і$ посудомийку можуть відзначити, і ще якусь працівницюю чи працівника із сфери побутового обслуговування! (М. Білкун); (10) Я робив, їв, пив, на когось сердився, хтось сердився на мене, щуось учиняв: добре чи лихе, але таке, щуо не виходило із меж прийнятого (В. Шевчук) і под.

5. Просторові прийменники реалізують свої потенціали в структурі синтагм, у поєднанні з повнозначним словом. У ліво- та правобічних контекстах просторові прийменники позначають статику 3 наголошенням: а) місцезнаходження предмета, в тому числі й б) на поверхні чи в) всередині іншого, або динаміку: 1) вихідний пункт руху (старт); 2) кінцевий пункт руху (фініш, фінал); 3) траєкторію руху і/чи переміщення (трасу - через предмет, повз нього чи в середині). У розгляді просторових прийменників істотним є врахування тріади локативність (де?) - адлативність (куди?) аблативність (звідки?), реалізація якої у слов'янських мовах очевидно є універсальною (Коницкая 2018: 132; Пипер 2014: 275-293; Lachur 2008: 440).

5.1. У синтагмальних контекстах статично-просторові прийменники виявляють себе як контактні (в/y, всередині/усередині, зверх, зверху, на, поверх/поверхи, посеред/посереду, посередині, серед²) й дистантні (біля, близько, близько від, близько до, близько з, далеко від, коло та ін.). Контактні прийменники поєднувані з формами місцевого й родового відмінків 3 ди-

2 У силу обмеженого простору в статті не деталізовано сполучуваність просторових прийменників з іменниково-відмінковими формами (Словник 2007). 
ференціюванням внутрішньої частини просторового орієнтира, його поверхні або центральної частини такої поверхні: (11) Флегматичний касир усередині каси ліньки позіхнув (Б. Антоненко-Давидович); (12) Він поклав книгу на ятку і розгорнув ї̈ (Ю. Винничук). Дистантні ж прийменники мають широкий значеннєвий діапазон, охоплюючи локалізацію: а) близькості ↔ віддаленості (біля, близько, близько від, близько до, близько з, далеко від, коло, недалеко, недалеко від, неподалік, неподалік від, оддалік/віддалік, оддалік/віддалік від, поодаль, побіля, поблизу/поблиз); б) загальну дистантну (поза, за); в) колову (довкола/довкіль, довкруг/довкруги, круг, кругом, навкруг/навкруги, округ (округи)); г) координатну (між орієнтирами: між, поміж, проміж); г) горизонтально-вертикальну (на чолі, навпроти / напроти, перед, поперед, попереду, проти, просто, супроти/насупроти, спереду): (13) Вперше за останній місяиь нахмарило і таки наближається гроза, бо гримить уже зовсім близько від міста (Б. Антоненко-Давидович); (14) Під стінами ж ізсередини городу та поза городом миготіли вогні руського стану (І. Білик); (15) Він прокопує глибокі рови довкруг веж і палаців, прихорошує покрівлі (О. Бердник); (16) Це був загалом звичний ранок, звична прогулянка поміж стеллажами (С. Андрухович); (17) Він весь час імов поперед мене, похитуючись $і$ безвільно баламбаючи довгими руками (Р. Андріяшик). Кожна з п’яти груп внутрішньо диференційована на певні різновиди, але найбільш насичена остання, в якій горизонтальна локалізація охоплює й місце перед орієнтиром (навпроти/напроти, перед, поперед, попереду, проти, просто, спереду, супроти/насупроти), й місце з тильної його сторони (за, ззаду, поза, позад/позаду), й місце збоку орієнтира (збоку, збоку від, обіч, обіч з, пообіч, пообіч з, поряд, поруч, поруч з, поруч від, поряд від), що може підлягати конкретизації (ліворуч, ліворуч від, осторонь від, праворуч, праворуч від), і місце з обох боків орієнтира (обабіч, обіруч, обіруч 3, обіруч від). Вертикальна ж локалізація орієнтована на визначення місця над просторовим орієнтиром (над/наді/надо, вище, повище) або під ним (nid/nidi/nido, nопід, нижче, понижче), а також тотожність знаходження (нарівні/врівні з).

5.2. Прийменниково-просторова семантика охоплює позначення шляху руху. Для контактних прийменників характерною є локалізація наскрізного руху (крізь, через): (18) Піднімалися стежкою, яка вела вгору через цвинтар (С. Андрухович), а дистантні можуть позначати локалізацію: 1) позаду орієнтира (вслід/услід, за, навздогін, навздогін за, позад/позаду, слідом за): (19) $i$ Лука кинувся б слідом за жінкою, намагаючись ї̈ наздогнати (С. Андрухович); 2) близько орієнтира (мимо, повз, попри, поряд з/із, проз): (20) Я протиснувся мимо чергового (Р. Андріяшик); 3) відносно зустрічного орієнтира (назустріч/навстріч): (21) Я вилетіла просто назустріч автобусові (С. Андрухович); (22) Із кам'янистих долин каламутними валами котилася навстріч подорожнім спека (П. Загребельний); 4) перетину, пересікання руху орієнтира (навперейми, напереріз): (23) Зайці з переляку чкурнули нам навперейми (Б. Антоненко-Давидович). 
Директивні прийменники (в/y, за, між/межи, на, над/надi/надо, перед/nереді/nередо, під, по, поза, поміж/помеж, понад/понаді, поперед/ попереду, попід, проміж/промеж) позначають або вихідний (від/од, з/із/зі, 3-за, з-межя/з-між, з-над, з-перед, з-під, з-поза, з-позад, з-поміж/з-яомежи, з-понад, з-поперед, з-попід, з-посеред, з-проміж/з-промеж, зсередини / ізсередини, починаючи від, починаючи з), або кінцевий (в/y, до, за, к (рідко), між/межи, на, над/наді/надо, перед/переді/передо, під/nidi/niдо, по, поза, поміж/помежи, поперед, попід/попідо, проміж, понад, у напрямі до, у напрямі на, у напрямку до, у напрямку на) пункти руху: (24) Я дбайливо намотав на ноги онучі, взувся і тільки в блузі вийшов з хати (Р. Андріяшик); (25) Місяџь зайшов за сильвету дзвіниці (І. Багряний). Контактні директивні прийменники деталізують трасу в межах орієнтира (3, 3-посеред, зсередини), його поверхні (з, зверху, згори) або в межах центра такого орієнтира (з-посеред, із середини), дистантні ж охоплюють: а) початок руху (від/од, починаючи від, починаючи з); б) напрям руху від орієнтира (від/од, з/iз/зi/зо); в) горизонтальне переміщення (з-за/із-за, з-позаду - з тильної сторони; 3-перед, з-поперед/з-попереду - від передньої частини); г) вертикальну локалізацію (3-над, з-понад - над орієнтиром; 3-nid/iз-nid, 3-попід/ із-попід — під орієнтиром; з-межи/з-між, з-поміж/із-поміж/з-помежи, 3-проміж - 3-посеред предметів).

5.3. Семантику фінального локатива передають прийменники $в / y$, вглиб/углиб, до, за, к (рідко), між/межи, на, над, насеред, перед, під/nidi/ nідо, поза, поміж/помежи, понад/понаді/понадо, поперед, попід/nonidi/ попідо, проміж, у напрямі до, у напрямку до, з-поміж яких контактні в/y, всередину, до, на концептуалізують рух до середини предмета або ж на його поверхню. Дистантні ж варіюють кінцеву точку: а) в/y, в бік, до, на, к (рідко), у напрямі до, у напрямку до - наближення до орієнтира; б) в/y, всередину, за, поза - переміщення у простір орієнтира з варіантним виявом обмеженого простору декількома орієнтирами: між/межи, поміж/помежи, промежи/проміж; в) перед/переді/передо, поперед/попереді/nопередо - спрямування з передньої сторони орієнтира; г) вище, вище від, над/ надi/надо, понад/понаді/понадо - переміщення в точку над орієнтиром; г) nid/nidi/nido, nonid/nonid/nonido - спрямування в точку під орієнтиром.

6. Утрачаючи просторову семантику, прийменник все більшою мірою граматизується, його функційний діапазон розширюється за рахунок вживання у немотивованому дієслівному керуванні, посилюється синтаксемотвірний потенціал. Мотивованим $є$ керування (іменне чи відмінкове прилягання), коли стрижневе слово визначає не прийменниково-відмінкову форму, а її смисл: (26) За якийсь час приїхав (звідки?) від неї з дорученням молодий гуиул (С. Андрухович); (27) Петя приїхав (звідки?) з полонини на своєму коні (С. Андрухович). Синтаксеми від неї, з полонини є вільними. Немотивованим постає керування у зв'язаних синтаксем, оскільки їхня форма визначувана стрижневим словом: (28) Я самовпевнено надіявся 
на свою пам'ять (Україна молода. 2020.12.06); (29) Останні подї̈ витіснили з моєї пам'яті пережите (Там само). Прийменники в зумовлених синтаксемах $\epsilon$ конструктивно визначеними: (30) На заводі працюють умілі фахівиі (Там само). Для вільних синтаксем лексикографічна практика має враховувати не лише формальну сполучуваність прийменників із відмінковими формами, а й лінійно позиційний, мотивований статус (співвідносність зі стрижневим дієсловом, девербативом та ін.) і встановлення смислових відтінків. У зв'язаних синтаксем істотним постає семантикосинтаксичний статус стрижневого компонента, що і ставить основним завданням укладання максимально вичерпних списків таких лексем, лексикографічне опрацювання. Аналіз прийменників у зумовлених синтаксемах має грунтуватися на відповідних синтаксичних структурах.

Прийменники просторової семантики за структурою диференційовані на моно- (до, з, з-за/із-за і под.) й полілексемні (ліворуч від, збоку від, убік $\partial о$ та ін.). 3-поміж останніх потрібно вирізняти інтервальні (дистактні) полілексемні: з/iз + Род. в. до + Род. в., вid /oд + Род. в. дo + Род. в.; $і з$ + Род. в. на + Знах. в.: (31) Трильовський перебрав понад усіляку міру $i$, колядуючи усім і всюди, ледве пересувався від хати до хати (С. Андрухович); (32) Лише наприкінці літа повернулися козаки з моря на Січ (А. Кащенко), що цілісно концептуалізують вихідний і кінцевий пункти руху з імпліцитно ж виявлюваним шляхом руху. Полілекксемні інтервальні прийменники доцільно кваліфікувати як цілісні утворення, розглядаючи в межах ініціальних лексем у словниках, у фінальних — подавати відповідне покликання.

7. Лексикографічний профіль прийменника (в широкому сенсі) з охопленням аналогів, еквівалентів (еквіприйменників) та ін. опрацьовано на грунті профілю часток (Загнітко - Каратаєва 2013: 5-35), що передбачає: 1) характерологію (структуру, походження, ступінь граматизації (аналог, еквівалент, у знач., оказіональний та ін.); 2) функційні вияви; 3) комунікативні вияви; 4) синтагматику; 5) семантико-парадигмальні ознаки (омоніми, антоніми, синоніми, варіанти); 6) квантитативні характеристики (за дискурсивними практиками); 7) динаміко-еволюційні параметри; 8) текстову маркованість; 9) нормативний / узусний статуси; 10) синтаксемотвірний потенціал (вільна, зв’язана, зумовлена синтаксеми); 11) тип відношень; 12) формально-граматичну позиційність; 13) етимологію та ін.

Просторова семантика в лексикографічному висвітленні $€$ найбільш скам'янілою, осмислювано відтворюваною і належить до ядра національно-когнітивної картини світу. Розширюючи відому тезу Л. Сльмслева про те, що «ні прийменникове керування не може існувати без прийменника, ні прийменник (типу sine) - без відмінка, яким він керує» (2006: 153), можна говорити про скам'яніння таких регулярностей та їх відображення в лексикографічних практиках із відповідною внутрішньою ієрархією значень у семантичній структурі прийменника, Своєрідним підтвердженням цього постає семантична структура прийменника $н а$, в якій із 40 зафіксованих 
значень (СУМ 11/5: 7) лише перші вісім є просторовими (із знах. і міси. в.). У категоризації простору активну участь бере іменниково-відмінкова форма, що спільно з прийменником може позначати: 1) спрямування дії на поверхню предмета (адлативність): залізти на піч, поставити на стіл; 2) місце розташування: сидіти на ослоні, висіти на тичці; 3) предмет як місце простору: думають на селі, померти на лазареті; 4) напрям руху (імпліцитний - шлях): прямувати на місто, поӥхати на село; 5) орієнтир руху: сходитися на вогонь, вийти на дзвінок та ін. (СУМ 20/9: 235-240). Побіжний погляд на словникову статтю прийменника на свідчить, що з восьми його просторових значень, найбагатшими на відтінки постають друге (шість) й третє (шість), що пов'язані з концептуалізацією переміщення (позначення предмета, місця, простору, в межі яких спрямована дія чи в межах яких відбувається дія — друге значення) або ж із позначенням 'місця, на якому або поблизу якого перебуває предмет, відбувається дія або на яке поширюється певний стан' (Там само: 225). Їх диференціювання визначуване мовцем. Його постать є тим орієнтиром, щодо якого в комунікативному акті структуровано й концептуалізовано простір (інтра- й екстралокалізацію, центральність і периферійність, горизонтальність і вертикальність, проксимальність і дистантність і под. (Пипер 2014: 285)). Постать мовця $\epsilon$ відправним моментом тлумачення ядерних дейктичних слів mym і mеnер (Апресян 1974: 77-78), а через них категоризації горизонтальної та вертикальної локалізації, її центральності та периферійності, а також статичної й динамічної і под. Просторові прийменники належать до національнокогнітивної бази, оскільки простір організований «навколо людини, яка ставить себе в центрі макро- й мікропростору» (Гак 2000: 127). Простір постає визначальним чинником людського буття. Перебування людини в просторі мотивує потребу його членування. Простір послідовно об'єктивований у мові, послідовно категоризуючись морфологічними, лексичними, синтаксичними та іншими засобами. Семіотичні опозиції «далеко - близько» $\mathrm{i}$ «верх - низ», очевидно, можна вважати універсальними й характерними для усіх мов. Функційне ж навантаження горизонтального й вертикального членування простору мотивоване відповідним ландшафтом проживання носіїв. Так, наприклад, за дослідженнями албанських казок, основу членування простору в них становить вертикальне, що відбиває відповідний простір, у якому шлях героя проходить «таким місцем, звідки можливий спуск і підйом» (Цивьян 1999: 59), а для української ментальності - основним постає горизонтальне. Так, наприклад, горизонтальне членування «далеко - близько» 3 варіантами «далеко від/далеко за близько від/недалеко / неподалік ↔ недалеко від/неподалік від»/ «далеко - поблизу $\rightarrow$ поблизу від» у кожному вияві деталізує членування простору: працювати далеко від України, бути далеко за Збручем, повести далеко за місто, спинитися недалеко села, розташуватися неподалік озеpa, перебувати неподалік від розвилки трьох доріг, проходити неподалік від колобочної, гриміти зовсім близько від міста, розташуватися побли- 
зу села, поблизу від нас кричати. Уточнювачі далеко, недалеко, неподалік, близько, поблизу актуалізують лінійну відстань і належать до формально-функційної структури прийменника, де недалеко і близько синоніми, хоча близько завжди активізує абсолютне наближення до постаті мовця.

8. Прийменник належить до тих силових сфер функціювання, які спрямовані на структурування реальності, постання ії елементів у різноманітних зв'язках і відношеннях (Пипер 2014: 279), де просторовість $є$ визначальною, оскільки поза нею нічого не відбувається. Активне розширення просторових прийменників через використання в їх функції аналогів, еквівалентів, набуття окремими іменниковими і/ чи прислівниковими формами лексикографічного статусу 'у знач.' ( $\leftrightarrow$ ‘у функції') свідчить про актуальну потребу доповнення граматичних засобів конкретизації різних просторових вимірів життєдіяльності людини, з одного боку, та відбиття в новітніх лексикографічних джерелах численних мовносоціумних об'єктивних дискурсивних практик, з другого боку. Функційно навантаженими постають зіставні студії прийменниково-просторових груп у різних мовах, що дає змогу простежити відмінність реалізації трьох- і двовимірного простору у мовних системах. Так, наприклад, у словенській мові поверх, вулиия, чужина концептуалізовані як трьохвимірні (v prvem nadstropju, živeti v ulici, iti v tujino (Коницкая 2018: 136; Klikovac 2006: 226-230), а в українській мові - як рівень, поверхня (мешкати на першому поверсі, проживати на вулииі, померти на чужині). Вербалізація просторовості має значний діапазон у мові, структурування й категоризація просторовості за кваліфікаційними ознаками горизонтальності та вертикальності, центральності та периферійності і под. найпослідовніше реалізується прийменниковими одиницями, дослідження яких вимагає покрокового встановлення причин нейтралізації первинної прийменникової семантики, формування на вторинному грунті функційно цілісних сполук слів.

\section{ЛІТЕРАТУРА}

Апресян Юрий. Лексическая семантика: синонимические средства языка. Москва: Наука, 1974.

Балабан Галина. Динамічні процеси в прийменниковій системі сучасної украӥнської літературної мови: автореф. ... канд. філол. наук. Київ, 2007.

Виноградов Виктор. Русский язык. Грамматическое учение о слове. Москва: Учпедгиз, 1947.

Виноградов Виктор. Русский язык (Грамматическое учение о слове). 4-е изд. Москва: Русский язык, 2001.

Виноградова Екатерина. «Русские предлоги в концепции М. В. Всеволодовой». Вестник Московского университета. Серия 9. Филология 5(2018): 230-246.

Вихованець Іван. Прийменникова система украӥнської мови. Київ: Наукова думка, 1984.

Вихованець Іван, Городенська Катерина. Теоретична морфологія украйнської мови. Київ: Пульсари, 2004.

Востоков Александр. Грамматика церковно-словенского языка. Кельн: Лингвистика, 1980.

Всеволодова Майя. «Предлог как грамматическая категория: проблемы дефиниции, типология, морфологические и синтаксические характеристики». Конюшкевич Мария 
(отв.) Вопросы функииональной грамматики. Гродно: Издательство Гродненского университета, 2002(4): 14-25.

Всеволодова Майя. «Система морфосинтаксических типов русских предлогов. Статья 1. Фрагмент системы - немотивированные (первообразные) предлоги». Вестник Московского университета. Серия 9. Филология 5(2012а): 30-78.

Всеволодова Майя. «Система морфосинтаксических типов русских предлогов. Статья 2: Фрагмент системы - мотивированные (вторичные) предлоги». Вестник Московского университета. Серия 9. Филология 6(2012b): 9-51.

Всеволодова Майя, Виноградова Екатерина, Чаплыгина Татьяна. Русские предлоги и средства предложного типа. Материаль к функичонально-грамматическому описанию реального употребления. Кн. 2: Реестр русских предложных единиц: $A$ - В (объективная грамматика). Москва: УРСС, 2018.

Гак Владимир. «Пространство вне пространства». Арутюнова Нина, Левонтина Ирина (отв. ред.), Логический анализ языка. Языки пространств. Москва: Наука, 2000: 127-134.

Ельмслев Луи. Пролегомены к теории языка. Москва: КомКнига, 2006.

Есперсен Отто. Философия грамматики. Москва: Издательство иностранной литературы, 1958.

Загнітко Анатолій та ін. Словник украӥнських прийменників. Сучасна украӥнська мова. Донецьк: ТОВ ВКФ «БАО», 2007.

Загнітко Анатолій, Каратаєва Анна. Словник часток: матеріали і статmі. Вид. 2-е, випр. і доп. Донецьк: ДонНУ. 2013.

Конюшкевич Мария. «Наше знание и незнание о предлоге». Русский язык и литература 11(2003): 75-83.

Конюшкевич Мария. «Русская предложная система в освещении М. В. Ломоносова». Коваль Владимир (отв. ред.) Традиции М. В. Ломоносова и современность. Гомель: Издательство Гомельского государственного университета, 2007: 14-19.

Конюшкевич Мария. «Релятивный потенциал имени». Лінгвістичні студіi 16(2008): 60-66.

Канюшкевіч Мария. Беларускія прыназоўнікі і іх аналагі. Граматыка рэальнага ўжывання. Матэрыялы да слоўніка : [У 3 ч.]. Гродна: ГрДУ, 2008-2010.

Коницкая Елена. «Структурно-семантические особенности словенских пространственных предлогов на фоне русских (квази)омонимов». Slavistica Vilnensis 63(2018): 129-157.

Курилович Ежи. Очерки по лингвистике. Биробиджан: Тривиум, 2000.

Кучеренко Ілля. Теоретичні питання граматики украӥнської мови: морфологія. Вид. 2-ге, уточ. й доповн. Вінниця: Поділля-2000, 2003.

Кущ Наталія. Прийменникова еквівалентність в украӥнській граматиці: структура, семантика, функиї: автореф. ... канд. філол. наук. Донецьк, 2009.

Ломоносов Михаил. Полное собрание сочинений. Том седьмой. Труды по филологии (17391758 г2.). Москва; Ленинград: Издательство Академии наук СССР, 1952.

Ляхур Чеслав. «Вторичные предлоги в польском языке - статус и характеристика (в связи с Международным проектом “Славянские в синхронии и диахронии: морфология и синтаксис")». Лінгвістичні студіï 17(2008): 75-79.

Мальцева Ольга. Предлог как средство концептуализации пространственньх отношений: дис. ... канд. филол. наук. Курск, 2004.

Мещанинов Иван. Члены предложения и части речи. Ленинград: Наука, 1978.

Мустайоки Арто. Теория функционального синтаксиса: от семантических структур к языковым средствам. Москва: Языки славянской культуры, 2006.

Нагайцева Нина. Предлоги. Харьков: Национальный технический университет «ХПИ», 2015.

Овсянико-Куликовский Дмитрий. Синтаксис русского языка. Санкт-Петербург: Издание Жуковского, 1902.

Падучева Елена. «Семантические роли и проблема сохранения инварианта при лексической деривации». Научно-техническая ифнормация. Серия 21 (1997): 18-30.

Пешковский Алексей. Русский синтаксис в научном освещении. Москва: Языки славянской культуры, 2001.

Пипер Предраг. «О простору у српској језичкој слици света». Slavistična revija 62/3(2014): $275-294$.

Потебня Александр. Из записок по русской грамматике: В 4-х т. Т. 4. Вып. 1. Москва: Просвещение, 1985. 
Русанівський Віталій. «Поняття семантичного і стилістичного інваріанта». Мовознавство 3(1981): 9-20.

Рыжкович Анна. «К вопросу о терминологическом статусе предлога». Universum 9/55(2018): $18-21$.

Садирова Бибинисо. Сопоставительный анализ предлогов, выражающих временные отношения в таджикском и английском языках: автореф. ... канд. филол. наук. Душанбе, 2014.

Словник української мови: В 11-и т. Київ: Наукова думка, 1970-1980.

Словник української мови: В 20-и т. Київ: Наукова думка; Український мовно-інформаційний фонд НАН України, 2012-2021.

Смолякова Наталья. «Вертикальное и горизонтальное членение пространства: семиотическое оппозиции «далеко - близко» и «верх - низ» (на материале говоров Среднего Приобья)». Молодой ученый 6/29. Т. 2(2011): 31-44.

Степаненко Микола. «Семантична диференціація просторових прийменників». Мовознавство 3(2015): 63-73.

Степанов Юрий. «Проблема классификации падежей». Вопросы языкознания 6(1968): 36-48.

Суровцева Светлана. Структурные и семантические свойства лексических и фразеологических темпоральных предлогов современного русского языка. Челябинск: Челябинский государственный педагогический университет, 2011.

Тарасевич Людмила. «Семантика пространственных предлогов в зеркале количественных показателей (на материале немецкого и русского языков». Веснік Беларускага дзяржаўнага універсітэта. Серыя 4. Мовазнаўства 2(2014): 40-47.

Теньер Люсьен. Основы структурного синтаксиса. Москва: Прогресс, 1988.

Урысон Е. В. «Предлог или наречие? Частеречный статус наречных предлогов». Bonpocы языкознания. 2017. № 5. С. 36-55.

Уфимцева А. А. Опыт изучения лексики как системы: на материале английского языка. Москва: URSS, 2020.

Цивьян Татьяна. Движение и путь в балканской модели мира. Исследование по структуре текста. Москва: Издательство «Индрик», 1999.

Шахматов Алексей. Синтаксис русского языка. Москва: Учпедгиз, 1941.

Щерба Лев. Языковая система и речевая деятельность. Москва: Наука, 1974.

Cook W. A. Case Grammar Theory. Wash. (D.C.): Georgetown University Press, 1989.

Fonstreuter E., Egerer-Moslein K. Die Prapositionen: VEB Verlag Enzyklopadie Leipzig. Leipzig, 1978.

Klikovac Duška. Semantika predloga: studia iz kognitivne lingvistike. Drugo izd. Beograd: Filološki fakultet, 2006.

Lachur Czeslaw. «O podstawach teoretycznych semantycznej kategorii ablatywności w językach słowiańskich». Acta Polono-Ruthenica XIII (2008): 437-446.

Lachur Czeslaw. Polskie przyimki wtórne i jednostki o funkcji przyimkowej w użyciu realnym: [materialy do stownika (w zestawlieniu z językiem rosyjskim)]. T. 1: a conto — oprócz. Opole, Kępa: Wydawnictwo NOWIK Sp.j., 2019.

Żeberek Teresa. Funkcjonowanie przyimków i wyrażeń przyimkowych w tekście rosyjskim i polskim. Kraków: Wydawnictwo Naukowe WSP, 1994.

Zgółkowa Halina. Funkcje syntaktyczne przyimkyw i wyrażeń przyimkowych we wspyłczesnej polszczyźnie mywionej, Poznań: Wydawnictwo Uniwersytetu Adama Mickewicza, 1980.

\section{СПИСОК ВИКОРИСТАНИХ ДЖЕРЕЛ}

Авраменко Олег, Авраменко Валентин. Реальна загроза. Київ: Джерела М, 2004.

Андріяшик Роман. Додому нема вороття. Люди зі страху. Київ: Радянський письменник, 1983.

Андрухович Софія. Літо Мілени. Київ: Смолоскип, 2002.

Антоненко-Давидович Борис. Твори: В 2-х т. Київ: Дніпро, 1991.

Бердник Олесь. Шляхи титанів. Київ: Радянський письменник, 1959.

Білий Дмитро. Заяложена душа. Донецьк: Альфа-прес, 2004.

Білик Іван. Меч Арея. Київ: Радянський письменник, 1972.

Білкун Микола. Корабель із райдужними вітрилами. Київ: Веселка, 1980. 
Винничук Юрій. Легенди Львова. Харків: Фоліо, 2018.

Доломан Євген. Вибрані твори. Київ: Довіра, 1989.

Дочинець Мирослав. Многії літа, благії літа. Заповіді 104-річного Андрія Ворона 一якдовго жити в щзасті і радості. Івано-Франківськ: Карпатська вежа, 2013.

Єшкілєв Володимир, Гуцуляк Олег. Адепт. Харків: Фоліо, 2012.

Загребельний Павло. Тисячолітній Миколай. Київ: Довіра, 1994.

Івченко Михайло. Робітні сили. Київ: Дніпро, 1990.

Кащенко Андріан. з Дніпра на Дунай. Вид. 3-тє. Відень - Катеринослав: Українське видавництво в Катеринославі, 1919.

Кідрук Максим. Навіжені в Мексииі. Київ: Клуб Сімейного Дозвілля, 2011.

Шевчук Валерій. Три листки за вікном. Київ: А-ба-ба-га-ла-ма-га, 2012.

\section{REFERENCES}

Apresyan Yurij. Leksicheskaya semantika: sinonimicheskie sredstva yazyka. Moskva: Nauka, 1974.

Balaban Galina. Dinamichni procesi v prijmennikovij sistemi suchasnoï ukraïns'koï literaturnoï movi. Avtoref. ... kand. filol. nauk. Kiïv, 2007.

Civ'yan Tat'yana. Dvizhenie i put'v balkanskoj modeli mira. Issledovanie po strukture teksta. Moskva: Izdatel'stvo «Indrik», 1999.

Cook W. A. Case Grammar Theory. Wash. (D. C.): Georgetown University Press, 1989.

Fonstreuter E., Egerer-Moslein K. Die Prapositionen: VEB Verlag Enzyklopadie Leipzig. Leipzig, 1978.

El'mslev Lui. Prolegomeny k teorii yazyka. Moskva: KomKniga, 2006.

Espersen Otto. Filosofiya grammatiki. Moskva: Izdatel'stvo inostrannoj literatury, 1958.

Gak Vladimir. «Prostranstvo vne prostranstva». Arutyunova Nina, Levontina Irina (otv. red.), Logicheskij analiz yazyka. Yazyki prostranstv. Moskva: Nauka, 2000: 127-134.

Klikovac Duška. Semantika predloga: studia iz kognitivne lingvistike. Drugo izd. Beograd: Filološki fakultet, 2006.

Konickaya Elena. «Strukturno-semanticheskie osobennosti slovenskih prostranstvennyh predlogov na fone russkih (kvazi) omonimov». Slavistica Vilnensis 63(2018): 129-157.

Konyushkevich Mariya. «Nashe znanie i neznanie o predloge». Russkij yazyk i literatura 11 (2003): 75-83.

Konyushkevich Mariya. «Russkaya predlozhnaya sistema v osveshchenii M. V. Lomonosova». Koval' Vladimir (otv. red.). Tradicii M V. Lomonosova i sovremennost'. Gomel': Izdatel'stvo Gomel'skogo gosudarstvennogo universiteta, 2007: 14-19.

Konyushkevich Mariya. «Relyativnyj potencial imeni». Lingvistichni studii 16(2008): 60-66.

Konyushkevich Mariya. Belaruskiya prynazoy̆niki i ih analagi. Gramatyka real'naga yzhyvannya. Materyyaly da sloy̆nika: [U 3 ch.]. Grodna: GrDU, 2008-2010.

Kucherenko Illia. Teoretychni pytannia hramatyky ukrainskoi movy: morfolohiia. Vyd. 2-he, utoch. y dopovn. Vinnytsia: Podillia-2000, 2003.

Kushch Nataliia. Pryimennykova ekvivalentnist v ukrainskii hramatytsi: struktura, semantyka, funktsii. Avtoref. ... kand. filol. nauk. Donec'k, 2009.

Kurilovich Ezhi. Ocherki po lingvistike. Birobidzhan: Trivium, 2000.

Lachur Czeslaw. «O podstawach teoretycznych semantycznej kategorii ablatywności w językach słowiańskich». Acta Polono-Ruthenica XIII (2008): 437-446.

Lachur Czeslaw. Polskie przyimki wtórne i jednostki o funkcji przyimkowej w użyciu realnym: [materialy do słownika (w zestawlieniu z językiem rosyjskim)]. T. 1: a conto - oprócz. Opole, Kępa: Wydawnictwo NOWIK Sp.j., 2019.

Lomonosov Mihail. Polnoe sobranie sochinenij. T. 7. Trudy po filologii (1739-1758 gg.). Moskva; Leningrad: Izdatel'stvo Akademii nauk SSSR, 1952.

Lyahur Cheslav. «Vtorichnye predlogi v pol'skom yazyke — status i harakteristika (v svyazi s Mezhdunarodnym proektom "Slavyanskie v sinhronii i diahronii: morfologiya i sintaksis")». Lingvistichni studiï 17(2008): 75-79.

Mal'ceva Ol'ga. Predlog kak sredstvo konceptualizacii prostranstvennyh otnoshenij. Avtoref. ... kand. filol. nauk. Kursk, 2004.

Meshchaninov Ivan. Chleny predlozheniya i chasti rechi. Leningrad: Nauka, 1978.

Mustajoki Arto. Teoriya funkcional'nogo sintaksisa: ot semanticheskih struktur $k$ yazykovym sredstvam. Moskva: Yazyki slavyanskoj kul’tury, 2006. 
Nagajceva Nina. Predlogi. Har'kov: Nacional'nyj tekhnicheskij universitet «HPI», 2015.

Ovsyaniko-Kulikovskij Dmitrij. Sintaksis russkogo yazyka. Sankt-Peterburg: Izdanie Zhukovskogo, 1902.

Paducheva Elena. «Semanticheskie roli i problema sohraneniya invarianta pri leksicheskoj derivacii». Nauchno-tekhnicheskaya ifnormaciya. Seriya 21 (1997): 18-30.

Peshkovskij Aleksej. Russkij sintaksis v nauchnom osveshchenii. Moskva: Yazyki slavyanskoj kul'tury, 2001.

Piper Predrag. «O prostoru u srpskoj jezichkoj slici sveta». Slavistična revija 62/3(2014): 275-294.

Potebnya Aleksandr. Iz zapisok po russkoj grammatike. V 4-h t. T. 4. Vyp. 1. Moskva: Prosveshchenie, 1985.

Rusanivskyi Vitalii. «Poniattia semantychnoho i stylistychnoho invarianta». Movoznavstvo 3 (1981): 9-20.

Ryzhkovich Anna. «K voprosu o terminologicheskom statuse predloga». Universum 9/55(2018): $18-21$.

Sadirova Bibiniso. Sopostavitel'nyj analiz predlogov, vyrazhayushchih vremennye otnosheniya $v$ tadzhikskom i anglijskom yazykah. Avtoref. ... kand. filol. nauk. Dushanbe, 2014.

Shahmatov Aleksej. Sintaksis russkogo yazyka. Moskva: Uchpedgiz, 1941.

Shcherba Lev. Yazykovaya sistema i rechevaya deyatel'nost'. Moskva: Nauka, 1974.

Slovnyk ukrainskoi movy: V 11-y t. Kyiv: Naukova dumka, 1970-1980.

Slovnyk ukrainskoi movy: V 20-y t. Kyiv: Naukova dumka; Ukrainskyi movno-informatsiinyi fond NAN Ukrainy, 2012-2021.

Smolyakova Natal'ya. «Vertikal'noe i gorizontal'noe chlenenie prostranstva: semioticheskoe oppozicii "daleko — blizko" i "verh — niz" (na materiale govorov Srednego Priob'ya)». Molodoj uchenyj 6/29. T. 2(2011): 31-44.

Stepanenko Mykola. «Semantychna dyferentsiatsiia prostorovykh pryimennykiv». Movoznavstvo 3 (2015): 63-73.

Stepanov Yurij. «Problema klassifikacii padezhej». Voprosy yazykoznaniya 6(1968): 36-48.

Surovceva Svetlana. Strukturnye i semanticheskie svojstva leksicheskih i frazeologicheskih temporal'nyh predlogov sovremennogo russkogo yazyka. Chelyabinsk: Chelyabinskij gosudarstvennyj pedagogicheskij universitet, 2011.

Tarasevich Lyudmila. «Semantika prostranstvennyh predlogov v zerkale kolichestvennyh pokazatelej (na materiale nemeckogo i russkogo yazykov». Vesnik Belaruskaga dzyarzhay̆naga universiteta. Seriya 4. Movaznay̆stva 2(2014): 40-47.

Ten'er Lyus'en. Osnovy strukturnogo sintaksisa. Moskva: Progress, 1988.

Ufimceva A. A. Opyt izucheniya leksiki kak sistemy: na materiale anglijskogo yazyka. Moskva: URSS, 2020.

Uryson E. V. «Predlog ili narechie? CHasterechnyj status narechnyh predlogov». Voprosy yazykoznaniya 5 (2017): 36-55.

Vykhovanets Ivan. Pryimennykova systema ukrainskoi movy. Kyiv: Naukova dumka, 1984.

Vykhovanets Ivan, Horodenska Kateryna. Teoretychna morfolohiia ukrainskoi movy. Kyiv: Pulsary, 2004.

Vinogradov Viktor. Russkij yazyk. Grammaticheskoe uchenie o slove. Moskva: Uchpedgiz, 1947.

Vinogradov Viktor. Russkij yazyk (Grammaticheskoe uchenie o slove). 4-e izd. Moskva: Russkij yazyk, 2001.

Vinogradova Ekaterina. «Russkie predlogi v koncepcii M. V. Vsevolodovoj». Vestnik Moskovskogo universiteta. Seriya 9. Filologiya 5(2018): 230-246.

Vostokov Aleksandr. Grammatika cerkovno-slovenskogo yazyka. Kel'n: Lingvistika, 1980.

Vsevolodova Majya. «Predlog kak grammaticheskaya kategoriya: problemy definicii, tipologiya, morfologicheskie i sintaksicheskie harakteristiki». Konyushkevich Mariya (otv.). Voprosy funkcional'noj grammatiki. Grodno: Izdatel'stvo Grodnenskogo universiteta, 2002(4): $14-25$.

Vsevolodova Majya. «Sistema morfosintaksicheskih tipov russkih predlogov. Stat'ya 1. Fragment sistemy - nemotivirovannye (pervoobraznye) predlogi». Vestnik Moskovskogo universiteta. Seriya 9. Filologiya 5(2012a): 30-78.

Vsevolodova Majya. «Sistema morfosintaksicheskih tipov russkih predlogov. Stat'ya 2: Fragment sistemy - motivirovannye (vtorichnye) predlogi». Vestnik Moskovskogo universiteta. Seriya 9. Filologiya 6(2012b): 9-51. 
Vsevolodova Majya, Vinogradova Ekaterina, Chaplygina Tat'yana. Russkie predlogi i sredstva predlozhnogo tipa. Materialy k funkcional'no-grammaticheskomu opisaniyu real'nogo upotrebleniya. Kn. 2: Reestr russkih predlozhnyh edinic: A - V (ob"ektivnaya grammatika). Moskva: URSS, 2018.

Zahnitko Anatolii ta in. Slovnyk ukrainskykh pryimennykiv. Suchasna ukrainska mova. Donec'k: TOV VKF «BAO», 2007.

Zahnitko Anatolii, Karataieva Anna. Slovnyk chastok: materialy i statti. Vyd. 2-e, vypr. i dop. Donec'k: DonNU. 2013.

Żeberek Teresa. Funkcjonowanie przyimków i wyrażeń przyimkowych w tekście rosyjskim i polskim. Kraków: Wydawnictwo Naukowe WSP, 1994.

Zgółkowa Halina. Funkcje syntaktyczne przyimkyw i wyrażeń przyimkowych we wspyłczesnej polszczyźnie mywionej, Poznań: Wydawnictwo Uniwersytetu Adama Mickewicza, 1980.

\title{
LIST OF WORKS
}

Avramenko Oleh, Avramenko Valentyn. Realna zahroza. Kyiv: Dzherela M, 2004.

Andriiashyk Roman. Dodomu nema vorottia. Liudy zi strakhu. Kyiv: Radianskyi pysmennyk, 1983.

Andrukhovych Sofiia. Lito Mileny. Kyiv: Smoloskyp, 2002

Antonenko-Davydovych Borys. Tvory: V 2-kh t. Kyiv: Dnipro, 1991.

Berdnyk Oles. Shliakhy tytaniv. Kyiv: Radianskyi pysmennyk, 1959.

Bilyi Dmytro. Zaialozhena dusha. Donetsk: Alfa-pres, 2004.

Bilyk Ivan. Mech Areia. Kyiv: Radianskyi pysmennyk, 1972.

Bilkun Mykola. Korabel iz raiduzhnymy vitrylamy. Kyiv: Veselka, 1980.

Vynnychuk Yurii. Lehendy Lvova. Kharkiv: Folio, 2018.

Doloman Yevhen. Vybrani tvory. Kyiv: Dovira, 1989.

Dochynets Myroslav. Mnohii lita, blahii lita. Zapovidi 104-richnoho Andriia Vorona - yak dovho zhyty $v$ shchasti i radosti. Ivano-Frankivsk: Karpatska vezha, 2013.

Yeshkiliev Volodymyr, Hutsuliak Oleh. Adept. Kharkiv: Folio, 2012.

Zahrebelnyi Pavlo. Tysiacholitnii Mykolai. Kyiv: Dovira, 1994.

Ivchenko Mykhailo. Robitni syly. Kyiv: Dnipro, 1990.

Kashchenko Andrian. Z Dnipra na Dunai. Vyd. 3-tie. Viden - Katerynoslav: Ukrainske vydavnytstvo v Katerynoslavi, 1919.

Kidruk Maksym. Navizheni v Meksytsi. Kyiv: Klub Simeinoho Dozvillia, 2011.

Shevchuk Valerii. Try lystky za viknom. Kyiv: A-ba-ba-ha-la-ma-ha, 2012.

\author{
Анатолиј Захнитко
}

\section{ПРЕДЛОШКО-ПРОСТОРНА СЕМАНТИКА У САВРЕМЕНИМ ТУМАЧЕњИМА: ГРАМАТИЧКЕ И ЛЕКСИКОГРАФСКЕ ДИМЕНЗИЈЕ}

Резиме

У раду је систематизована еволуција становишта о предлозима и њиховој квалификацији у формалној (формално-граматичкој), семантичкој, функционално-комуникативној, функционално-когнитивној димензији са фокусом на предлошко-просторну семантику, која је дефинисана као примарни и хијерархијски врхунац у функционално-когнитивној и функционално-комуникативној димензији. Просторна семантика чини језгро предлошког система, његову постепену редукцију (↔ губитак) изазива формирање функционално интегралних фраза у којима се предлошка компонента граматизује и постаје актуализатор просторног параметра - дубине, дужине, ширине, висине, а примарна предметна семантика се неутралише, остаје само формално-граматички садржај. Понуђен је лексикографски профил предлога просторне семантике.

Кључне речи: предлог, предлошка јединица, предлошко-просторна семантика, спецификатор реченице, предлошка компонента, приглаголска позиција, предлошки профил. 